\title{
The Effect of Guest Lecturers and Online Discussion Forum Towards Students' Communication Competencies on English for Educational Technologist Course
}

\author{
Luh Putu Putrini Mahadewi ${ }^{1 *}$, Ketut Pudjawan ${ }^{1}$ \\ ${ }^{1}$ Faculty of Educational Science, Universitas Pendidikan Ganesha, Singaraja, Bali 81116, Indonesia \\ *Corresponding author. Email: lpp-mahadewi@undiksha.ac.id
}

\begin{abstract}
Rapid development of ICT, especially in the 4.0 industrial revolution era has brought impacts on human's life including in education. One of the impacts is learning can be conducted anytime and anywhere through online learning setting. Despite of the high potential ability of ICT development can bring, strategies to deliver online class remain hold important roles to the successful of online learning. So far, limited online learning strategies were implemented to teach students in online classes at the Department of Educational Technology at Universitas Pendidikan Ganesha. Because of it, effective online learning strategies are needed. The goal of this research was to test the effect of guest lecturers and online discussion forum toward students' communication competencies on English for Educational Technologist course. The current research is a quasi-experiment research. The research design is post-test control group design. Subjects of the research are all students who were taking English for Educational Technologist course. The method that was used to collect the data are performance test. Based on the method, the instrument used to collect the data was a performance test rubric. The collected data were then analysed by using descriptive technique and inferential statistical technique. The results show the implementation of guest lecturers and online discussion forum has significant effect toward students' communication competencies on English for Educational Technologist course. Students' become highly motivated to learn the learning materials and actively involved in the discussion forums. Based on the research results, further studies on effectiveness of online learning strategies are strongly recommended.
\end{abstract}

Keywords: Guest Lecturers, Online Discussion Forum, Online Learning

\section{INTRODUCTION}

The rapid development of information communication and technology (ICT) in the 4th industrial revolution era has brought impacts to every sector of human's life, including in education. One of the impacts in education sector is indicated by the existence of educational programs without distance and time boundaries. Instruction can be conducted anytime and anywhere. Because of this, the instruction especially in higher education is become flexible for the students.

The instruction that integrates online class and faceto-face learning is very potential to be developed in order to improve the access of learning, students' enrollment and retention, particularly in higher education as change of agent [1]. Moreover, in the situation of pandemic
Covid-19, studying in face-to-face setting is suggested to be avoided and online learning is encouraged.

The more a university adopts online learning, the better understand and design courses suitable for the online environment are needed [2]. The Department of Educational Technology at Universitas Pendidikan Ganesha (Undiksha) has conducted varies innovation in instruction including developing online courses by using University's online platforms since 2010. The developed online courses not only to supplement the face-to-face learning but also to complement the whole learning activities and contribute to students' final grades. For this reason, the development of online courses also considered students' cognitive load and their comfortabilities in studying online. 
So far, online courses development focused on students' cognitive load during their studies online, for example online learning materials presentations by the lecturers. Limited online learning strategies were implemented to teach students in online classes. Despite of the high potential ability of ICT development can bring, engagement strategies to deliver online class remain hold important roles to the successful of online learning [3]. Because of it, effective online learning strategies are needed.

One of the online courses offers in the Department of Educational Technology in Undiksha is English for Educational Technologist. This is a new course intended for the students to master communication competency of educational technology related content in English. Therefore, effective online learning strategies are needed. Not only for the students to master the learning content, but also for them to communicate it. There are many learning strategies that can be tested to find the best online learning strategy, particularly for English for Educational Technologist course. Some of the online learning strategies are guest lecturers and discussion forum. The goal of this research is to test the effectiveness of guest lecturers and online discussion forum toward students' communication competencies on English for Educational Technologist course.

\subsection{Related Work}

\subsubsection{Communication Competencies}

Communication involves art and process of creating and sharing ideas. The richness of the ideas defines the effectiveness of the communication. Communication competencies are the tools for effective communication and are used to remove the barriers (different cultures, different perspectives, different communication styles) occur during communication process [4]. There are four basic communication skills/competencies: listening, reading, writing and speaking. Considering students' diversity, innovative learning strategies need to be applied in facilitating the students to master effective and impressive communication skills [5].

\subsubsection{Guest Lecturers}

Engaging students in their online learning requires continuous effort as they are always desperate to have learning variety in their study. Strategies to deliver online learning are believed as one of the key points of the successful of online learning, including guest lecturers.

Although little is known regarding the impact of guest lecturers on students' communication competencies, some related studies showed the significant of guest lecturers as effective online learning strategy. Guest lecturers enhanced students' critical thinking skills and interest level during asynchronous discussion [6]. Moreover, guest lecturers bring relevance topic, increase students' interest and involvement [7].

The use of guest lecturers in online learning significantly or somewhat enhanced the instruction, in synchronous or asynchronous activities, although there were technological and scheduling concerns [8]. Guest lecturers provided connection for student to working professional in the profession for student aspiring to join.

\subsubsection{Online Discussion Forum}

It is believed that online discussion forum offers a very helpful environment for lecturer-student collaboration. This online learning strategies has benefits, such as: enables the students to participate in online forums than in large group classroom discussions, encourages students who do not participate during the face-to-face discussion to become vocal during online discussion, students and lecturers frequently think of comments or questions after lecture and can post those comments and questions on the online forum provided [9].

Online discussion forum is one of the most effective online learning tools for collaborative learning that can enrich students' learning experiences by promoting reflection, analysis, and higher-order thinking [10]. Furthermore, combining online discussion forum and other online learning strategy offered students a highquality of online learning environment. By transferring discussion to an online environment, opportunities for learning from each other have improved [11].

In order to attract the students to actively involve during the online discussion forum, offering incentives to participate in the discussion forum and creating a positive community environment, are two among many other initiatives that might be applied [12].

\subsection{Our Contribution}

Conducting researches on the effectiveness of online learning strategies are very urgent. The research results then can be used as references to select the appropriate online learning strategy to facilitate online students optimally. It needs to be underlined that online learning strategy defines the learning activities and content delivery of the courses. The contribution of this paper is to enrich the empirical evidence of online learning strategies implementation, particularly guest lecturers and online discussion forum strategies. Furthermore, this paper contributes to the variety of online learning strategies that best serve the online students to study their best. As potential engaging online learning strategies, both guest lecturers and online discussion forum are believed can improve students' communication competencies. 


\subsection{Paper Structure}

The structure of the paper is organized as follows. Section 2 introduces the research method including the research design, subject, method and instrument to collect the data and data analysis. Section 3 presents the finding and discussion. Section 4 concludes the research result.

\section{METHOD}

This is a quasi-experiment research and the research design is post-test control group design. There were two groups taught by using different learning strategies. The first group was an experimental group consisted of 21 students who were taught by using guest lecturers and online discussion forum. The other group was a control group consisted of 21 students who were taught by using online lecturing by the initial lecturer only.

Students' communication competencies were collected by using a rubric. The rubric consists of four items related to communication competencies the students should mastered. Score for each item of the rubric was divided into five scales that best described each student communication competency. Then, collected data were analyzed by using descriptive technique and inferential statistical technique.

\section{FINDING AND DISCUSSION}

This research is to test the effectiveness of online learning strategies. Students in control group were taught by using online lecturing strategy and the students in experiment group were taught by using guest lecturers and online discussion forum.

The descriptive technique shows students' communication competencies for both groups as seen on Figure 1 and Figure 2.

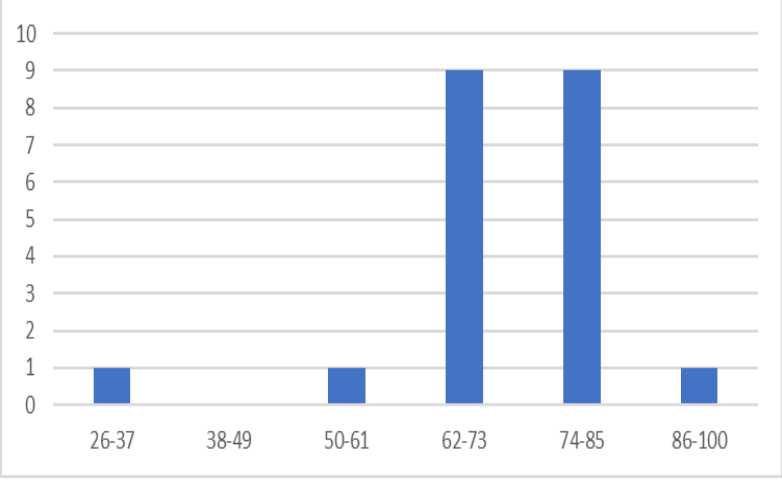

Figure 1 Students' Communication Competencies in control group.

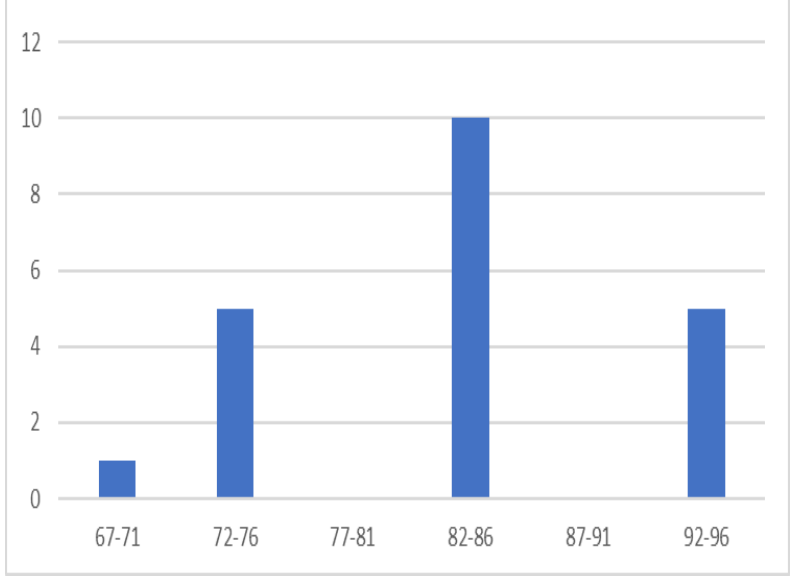

Figure 2 Students' Communication Competencies in experiment group

Both figures, Figure 1 and Figure 2 show students communication competencies after taking English for Educational Technologist online course. The mean score of control group was 71,714 while the mean score of experiment group was 82,476 . It means the mean score of experiment group is higher than the mean score of control group.

Table 1. Tests of Normality

\begin{tabular}{|c|c|c|c|c|c|c|c|}
\hline \multirow{2}{*}{} & \multirow{2}{*}{ Group } & \multicolumn{2}{|c|}{ Kolmogorov-Smirnov } & \multicolumn{4}{c|}{ Shapiro-Wilk } \\
\cline { 2 - 9 } & & Statistic & df & Sig. & Statistic & df & Sig. \\
\hline \multirow{2}{*}{$\begin{array}{c}\text { Communication } \\
\text { Competencies }\end{array}$} & Control Group & .265 & 21 & .000 & .801 & 21 & .001 \\
\cline { 2 - 9 } & Experiment Group & .244 & 21 & .002 & .866 & 21 & .008 \\
\hline
\end{tabular}

a. Lilliefors Significance Correction 
Table 2. Test of Homogeneity of Variance

\begin{tabular}{|l|l|r|r|r|r|}
\hline \multicolumn{2}{|c|}{} & \multicolumn{1}{c|}{$\begin{array}{c}\text { Levene } \\
\text { Statistic }\end{array}$} & df1 & \multicolumn{1}{c|}{ Sig. } \\
\hline \multirow{4}{*}{$\begin{array}{l}\text { Communication } \\
\text { Competencies }\end{array}$} & Based on Mean & 2.175 & 1 & 40 & .148 \\
\cline { 2 - 6 } & Based on Median & 2.223 & 1 & 40 & .144 \\
\cline { 2 - 6 } & $\begin{array}{l}\text { Based on Median and with } \\
\text { adjusted df }\end{array}$ & 2.223 & 1 & 29.149 & .147 \\
\cline { 2 - 6 } & Based on trimmed mean & 2.381 & 1 & 40 & .131 \\
\hline
\end{tabular}

By using Shapiro-Will data analysis technique, it was found that both groups were not normally distributed although they were homogenous. Non-parametric statistical technique was used. The Wilcoxon Rank Sum Test is non-parametric statistical technique use to analyze the same number of samples in both groups and were less than 25 . In this research, both groups were consisted of 21 students. The research hypothesis is accepted if the Wobs value is smaller than Wcv

Table 3. Wilcoxon Rank Sum Test (or Mann-Whitney) Test

Rank

\begin{tabular}{|l|l|r|r|r|}
\hline & Group & N & Mean Rank & Sum of Ranks \\
\hline \multirow{4}{*}{ Communication Competencies } & Control Group & 21 & 15.48 & 325.00 \\
\cline { 2 - 5 } & Experiment Group & 21 & 27.52 & 578.00 \\
\cline { 2 - 5 } & Total & 42 & & \\
\hline
\end{tabular}

Test Statistics ${ }^{\mathrm{a}}$

\begin{tabular}{|l|r|}
\hline & Communication Competencies \\
\hline Mann-Whitney U & 94.000 \\
\hline Wilcoxon W & 325.000 \\
\hline Z & -3.285 \\
\hline Asymp. Sig. (2-tailed) & .001 \\
\hline a. Grouping Variable: Group & . \\
\hline
\end{tabular}

Table 3 shows the value of Sig. (2-tailed) was .001 lower than the level of standard $(\alpha=.05)$. The meaning of this value is there was a significant difference in the sum of ranks between the control and experimental group. Experiment group is higher than control group. It means, guest lecturers and online discussion forum has significant effect toward students' communication competencies on English for Educational Technologist course.

Guest lecturers stimulated students' attentions to carefully listened to the information delivered by the sixth invited guest lecturers. The students stated that were worried of missing any detail information provided by each guest lecturer. To deliver course materials by inviting guest lecturers has significant effect in improving students' learning results. Guest lecturers have the ability to promote better teaching outcomes [13].

Online discussion forum provided the students an opportunity to actively express their thought after they listened to the lecturers. In details, implementing online discussion forum leads the students to obtain a better achievement [14]. Additionally, online discussion forum could improve students' academic performance by identifying students' learning need and modifying the educational materials and delivery according to the expressed needs [15]. 
Guest lecturers and also online discussion forum can bring social presence dimension in online class [13]. It stimulates students' engagement in online course as indicated on their competencies. Delivering learning materials by inviting guest lecturers (specifically from professionals) followed by discussion forum facilitated the students to achieve the desire communication competencies. Online learning tools provide students with the ability to interact with guests in new ways by expressing individual concerns and discussing them without time and place constraints [17]

\section{CONCLUSION}

Based on finding and discussion, it can be concluded that guest lecturers and online discussion forum has significant effect toward students' communication competencies on English for Educational Technologist course. The combination of online learning strategies provided better learning results rather than only one learning strategy.

\section{ACKNOWLEDGMENT}

This study was supported by the Research and Community Services Institution (Lembaga Penelitian dan Pengabdian Kepada Masyarakat/LPPPM) of Universitas Pendidikan Ganesha.

\section{REFERENCES}

[1] A. Sun, X. Chen, Online education and its effective practice: a research review, Journal of Information Technology Education: Research 15 (2016), pp. 157-190. DOI: https://doi.org/10.28945/3502.

[2] J. Costello, Perception of guest lecturers' impact on online learning communities, in: Proceedings of the 8th International Conference on Networked Learning, Lancaster University, UK, 2012, pp. 482487.

[3] F. Martin, D.U. Bolliger, Engagement matters: Student perceptions on the importance of engagement strategies in the online learning environment, Online Learning 22(1) (2018) 205222. DOI: https://doi.org/10.24059/olj.v22i1.1092.

[4] MTD Training, Effective communication skills, MTD Training and Ventus Publishing, 2010.

[5] S. R. Khambayat, Developing effective communication skills in students, Scholarly Research Journal for Interdisciplinary Studies, 4(37) (2017) 8799-8817.

DOI: https://doi.org/10.21922/srjis.v4i37.10829.

[6] L. S., Hemphill, H.H. Hemphill, Evaluating the impact of guest speaker posting in online dicussions, Bristish Journal of Educational Technology 38(2)
(2007) 287-293. DOI: https://doi.org/10.1111/j.1467-8535.2006.00622.x.

[7] L. Li, R. Guo, A student-centered guest lecturing: a constructivism approach to promote student engagement, Journal of Instructional Pedagogis 15 (2015) 1-7.

[8] E. Rogers, H.S. Carrier, Effective use of "guest lecturers" in online instruction, in: Proceedings of the Distance Learning Administration (DLA), University of West Georgia, Carrollton, Georgia, 2018, pp. 157-162.

[9] A.H. Biriyai, E.V. Thomas, Online discussion forum: a tool for effective student-teacher interaction, International Journal of Applied Science (IJAS) 1(1) (2014) 111-116. DOI: https://doi.org/10.2139/ssm. 2525047.

[10] M., N. AlJeraisy, H. Mohammad, H.A. Fayyoumi, W. Alrashideh, Web 2.0 in education: the impact of discussion board on student performance and satisfaction, TOJET: The Turkish Online Journal of Educational Technology 14(2) (2015) 247-258.

[11] R. Seethamraju, Effectiveness of using online discussion forum for cases study analysis, Educational Research International (2014) 1-10. DOI: https://doi.org/10.1155/2014/589860.

[12] J. Xia, J. Fielder, L. Siragusa, Achieving better peer interactions in online discussion forum: a reflective practitioner case study, Isssues in Educational Research 23(1) (2013) 97-113.

[13] P. Zou, W. Sun, S.G. Hallowell, Y. Luo, C. Lee, L. $\mathrm{Ge}$, Use of guest speakers in nursing education: an integrative review of multidisciplinary literature, Advances in Medical Education and Practice, 10, 2019 175-189. DOI://doi.org/10.2147/AMEP.S196456.

[14] M.G. Alzahrani, the effect of using online discussion forums on students' learning, The Turkish Online Journal of Educational Technology (TOJET), 16(1) (2017) 164-176.

[15] N. Waheed, Effect of an online discussion forum on student engagement and learning in a first year undergraduate nursing unit an action research study, conference paper, $2017 . \quad$ DOI: https://doi.org/10.5176/2315-4330_WNC17.35.

[16] W. Huang, A. HurtJ.C. Richardson, K. Swan, S. Caskurlu. Community of inquiry framework, Purdue University Repository for Online Teaching and Learning, 2020.

[17] S. Kumari, Connecting graduate students to virtual guests through asynchronous discussions-analysis of an experience, JALN 5(2) (2001) 53-63. 